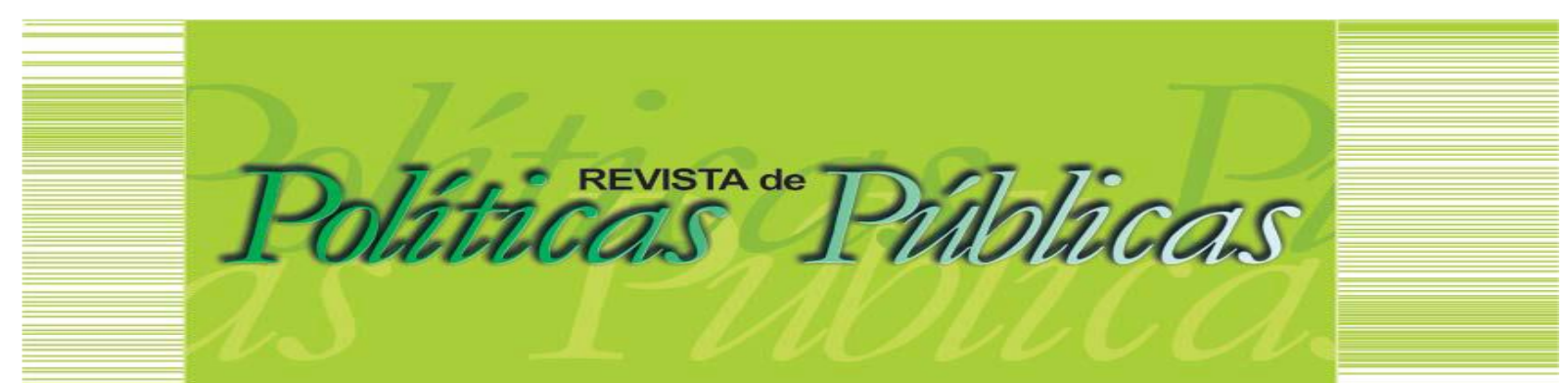

\title{
COVID-19 E INFORMALIDADE URBANA: diálogos entre Moçambique e Brasil
}

\author{
Gabriel Barros Bordignon 1 \\ Jacinta Francisco Dias² \\ Alefe Abraão da Silva dos Santos 3
}

\section{Resumo}

O presente artigo investiga a questão da informalidade urbana no contexto da pandemia de COVID-19 em Moçambique e Brasil através de um diálogo entre as cidades de Pemba (Cabo Delgado) e Duque de Caxias (Rio de Janeiro), que revela a grande disparidade socioeconômica, política e conjuntural entre os dois países. A pesquisa se apoia em revisão bibliográfica e documental de produções científicas, relatórios nacionais e internacionais, dados censitários governamentais e institucionais, entrevistas informais e cobertura midiática a respeito da questão da informalidade urbana e da pandemia de COVID-19 nos dois países. 0 trabalho reflete sobre as condições de cumprimento das recomendações hegemônicas, centradas na OMS; apresenta cenários atuais e dados gerais;eanalisa discursos oficiais e ações governamentais no que se refere às posturas frente à pandemia.Por fim,demonstracomo a presença da informalidade urbana histórica, dadas as condições socioeconômicas e posturaserráticasdos poderes públicos,são questões determinantes para a situação da saúde pública e das vidas das populações em Moçambique e Brasil no contexto pandêmico, apontando para a necessidade de políticas públicas integradas, abrangentes, e que contemplem, também, especificidades locais.

Palavras-chave: COVID-19; Informalidade; Moçambique; Brasil.

\section{COVID-19 AND URBAN INFORMALITY: dialogues between Mozambique and Brazil}

\begin{abstract}
The present article investigates the urban informality in the context of the COVID-19 pandemic in Mozambique and Brazil through a dialogue between the cities of Pemba (Cabo Delgado) and Duque de Caxias (Rio de Janeiro), which reveals the great socioeconomic, political and conjuncture disparity between the two countries. The research is supported by bibliographic and documentary review of scientific productions, national and international reports, government and institutional census data, informal interviews and media coverage on the issue of urban informality and the COVID-19 pandemic in both countries. The work reflects on the conditions of compliance with the hegemonic recommendations, centered on the WHO/OMS(PT); presents current scenarios and general data; and analyzes official speeches and governmental actions with regard to the attitudes to the pandemic. Finally, it demonstrates how the presence of historic urban informality, given the socioeconomic conditions and erratic postures of public authorities, are decisive for the situation of public health and the lives of populations in Mozambique and Brazil in the pandemic context, pointing to the need for integrated, comprehensive public policies that also include local specificities.
\end{abstract}

Keywords: COVID-19. Informality. Mozambique. Brazil

Artigo recebido em: 21/12/2020 Aprovado em: 27/05/2021 DOI: http://dx.doi.org/10.18764/2178-2865.v25n1p104-129

${ }^{1}$ Arquiteto e Urbanista. Mestre em Arquitetura e Urbanismo pelo Programa de Pós-graduação em Arquitetura e Urbanismo (PPGAU) da Universidade Federal de Uberlândia (UFU). Pesquisador de Doutorado pelo Programa de Pós-graduação em Arquitetura e Urbanismo (PPG-AU) da Universidade Federal da Bahia (UFBA). E-mail: gbordignon@ufba.br

${ }^{2}$ Graduada em História Política e Gestão Pública. Mestre em Ciências Políticas e Estudos Africanos pela Universidade Pedagógica de Moçambique. Pesquisadora de Doutorado e Bolsista da Fundação de Amparo à Pesquisa do Estado da Bahia (FAPESB) pelo Programa de Pós-graduação em Arquitetura e Urbanismo (PPG-AU) da Universidade Federal da Bahia (UFBA). E-mail: diasjack02@gmail.com

${ }^{3}$ Técnico em Edificações. Técnico em Edificações pela Fundação de Apoio à Escola Técnica do Rio de Janeiro (FAETECRJ). Estudante de Graduação em Arquitetura e Urbanismo pela Faculdade de Arquitetura da Universidade Federal da Bahia (FAUFBA).E-mail: alefe.abraao@ufba.br 


\section{INTRODUÇÃO}

A pandemia de COVID-19 tornou patentes algumas questões urbanas, já existentes, sobretudo em cidades do sul global, como a desigualdade socioespacial, deficiências na mobilidade urbana, ausência de infraestruturas básicas de saneamento e abastecimento de água em regiões mais pobres, entre outras. A questão da informalidade urbana, abrangendo moradia e trabalho, é um dos pontos centrais para se refletir sobre o impacto do novo coronavírus em países como Moçambique e Brasil, que possuem parcela considerável de suas populações vivendo e trabalhando em condições informais. A presente pesquisa, nesse contexto, investiga a seguinte situação paradoxal:

1) o vírus se dissemina principalmente por vias aéreas, ou seja, é necessário evitar aglomerações em locais fechados;

2) os órgãos reguladores de saúde, nacionais e internacionais, recomendam paralisações de atividades diversas e isolamento social;

3) as pessoas que vivem na informalidade devem se decidir entre: sair de casa, desobedecendo as recomendações, e correr o risco de contrair a doença, ou permanecer em uma residência possivelmente precária e compartilhada com muitas pessoas, sem condições de trabalhar;

4) o papel dos Estados, na resolução de tais imbróglios, não é cumprido de maneira efetiva. Esse cenário indica a importância de se analisar a conjuntura atual, de forma a contribuir com presentes e futuras políticas públicas, visto 0 ainda corrente contexto pandêmico.

A pesquisa se apoia em revisão bibliográfica e documental de produções científicas, relatórios nacionais e internacionais, dados censitários governamentais e institucionais, entrevistas informais e cobertura midiática a respeito da questão da informalidade urbana e da pandemia de COVID-19 em Moçambique e Brasil, fazendo um diálogo entre as cidades de Pemba (província de Cabo Delgado) e Duque de Caxias (estado do Rio de Janeiro). As análises refletem sobre as condições de cumprimento das recomendações hegemônicas, centradas na OMS; apresentam cenários atuais e dados gerais; e analisam discursos oficiais e ações governamentais no que se refere às posturas dos dois países frente à pandemia.

Como resultado, o trabalho demonstra como a informalidade - dentro dos contextos socioeconômicos apresentados e diante das posturas erráticas dos poderes públicos em diversas esferas - é determinante para a situação da saúde pública e das vidas das populações em Moçambique e Brasil na pandemia de COVID-19, alertando para a urgência de políticas públicas que priorizem as vidas humanas sobre outras questões como a própria economia, que sejam integradas, planejadas e coordenadas entre diferentes níveis de poder, desde o estatal até o local, e que seja abrangente e inclusiva, não alcançando apenas as parcelas das populações presentes nos bancos de 
dados oficiais, mas também as que se fazem à margem das estatísticas, que são as mais afetadas pela pandemia, ainda sem um fim em vista.

Em dezembro de 2019, o governo da China anuncia à Organização Mundial da Saúde sobre a existência de casos de pneumonia de etiologia desconhecida, detectados na cidade de Wuhan, capital da província de Hubei. Já no dia 11 de janeiro de 2020, o país registra o primeiro óbito causado pela COVID-19 (DEUTSCHE WELLE, 2020a). A partir desse período, instituem-se instrumentos e medidas para a mitigação da doença a nível global;a OMS divulga normas e procedimentos de orientação para países em diversas frentes, como modos de transmissão, tratamentos, prevenção, redução de propagação e mortalidade(OPAS; OMS, 2020a).Ainda em janeiro, registravam-seinfecções em outros países, inicialmente na Tailândia, Japão e Coreia do Sul; porém, no mesmo mês, já havia casos fora da Ásia (SANTIRSO, 2020).

Com o espalhamento acelerado da doença pelo mundo, esperava-se a devastação dos países em vias de desenvolvimento, onde as condições sanitárias e de saneamento deixam a desejar. Com efeito, os primeiros casos de contaminação na África subsaariana foram oficialmente registrados em Lagos, na Nigéria (28 de fevereiro) e Dacar, no Senegal (02 de março) (ESTADO DE MINAS; GAZETA DO POVO, 2020). Neste contexto, os governos dos países africanos, preocupados com a insalubridade e a informalidade - que representa o modo de vida de mais de $60 \%$ da população das cidades do continente - adotaram políticas, medidas e protocolos de prevenção e tratamento semelhantes aos do resto do mundo (MONIÉ, 2020).

De acordo com Krippahl (2020), uma análise da think-tank estadunidense Rand Corporation aponta que em 2016, dos 25 países mais vulneráveis a surtos infeciosos, 22 encontravamse em África. Diante deste cenário, a OMS mostrou-se preocupada com as condições do continente diante da inevitável chegada da COVID-19, por conta da fraca rede sanitária, da aglomeração populacional em centros urbanos e da falta de unidades de cuidados intensivos e equipamento pessoal especializado. A África do Sul foi o país mais atingido pela pandemia dentre os países da África austral, tendo registrado seus primeiros casos no início de março, enquanto Moçambique registrou seu primeiro caso em 22 do mesmo mês (DEUTSCHE WELLE, 2020b), um homem idoso que retornara de viagem ao Reino Unido.

O primeiro caso no Brasil foi confirmado em 26 de fevereiro, contudo, por conta do período de incubação do vírus, é possível que a doença já estivesse em circulação no país antes dessa data, por conta do carnaval, que reúne diversos estrangeiros. O 'paciente zero' é um homem de São Paulo que havia visitado a Itália(OLIVEIRA; BORGES; BEDINELLI, 2020). Assim como em vários países do mundo, a COVID-19 chegou ao Brasil por aeroportos de grandes centros urbanos, ou seja, os primeiros infectados foram pessoas com maior renda e a concentração deu-se, inicialmente em bairros mais 


\section{COVID-19 E INFORMALIDADE URBANA: diálogos entre Moçambique e Brasil}

ricos. Entretanto, a crença de que o vírus atingiria somente a população mais abastada foi logo desmentida. 0 novo coronavírus alcançou gravemente as periferias e a desigualdade socioespacial brasileira foi mais ainda evidenciada.

Em 11 de março, a OMS eleva a contaminação por COVID-19 ao status de pandemia (OPAS; OMS, 2020b).Vale pontuar que Moçambique e Brasil tiveram um tempo considerável de preparo para suas políticas públicas de saúde antes da chegada da doença, ou no início de sua disseminação, quando ainda lenta. A rede de informações científicas trabalhava com colaborações globais e havia exemplos mundiais de alta e baixa eficiênciano enfrentamento do vírus. Entretanto, diversospaíses apresentaram dificuldades de implementação de ações efetivas como as recomendadas pelos discursos hegemônicos por razões políticas, socioeconômicas e contextuais. 0 novo coronavírus afetou Moçambique e Brasil com intensidades e formas bastante díspares; dessa forma, propõe-se um diálogo sobre pontos de convergência e principais diferenças entre os casos, tendo como linha guia da discussão a questão da informalidade urbana.

Gonçalves, Bautès e Maneiro (2018) apontam que a produção de informalidade é geralmente explicada por discursos de domínio econômico. Para Alexander (2019), economista do setor de estatística do FMI, a economia informal é definida por "atividades econômicas à margem da economia regulada e do sistema tributário". Tal visão dualista é adotada também por outras organizações internacionais como o BID, ou nacionais como o IBGE. O setor informal é composto por atividades com baixo nível de organização, pouca ou nenhuma divisão de capital, baixa escala de produção e exercidas por famílias organizadas em empresas não registradas (OLINTO, 2020).

A Organização Internacional do Trabalho define 'trabalho formal' como ocupações onde haja benefícios associados - em outros termos, direitos trabalhistas - todas as demais categorias de trabalho são, portanto, informais. Até 2017, as regiões com maior porcentagem do PIB advinda da economia informal, com média de $34 \%$, foram a África Subsaariana e a América Latina e Caribe (ALEXANDER, 2019).

Contudo, o presente trabalho opta por assumir uma visão ampliada da informalidade, não a compreendendo apenas como oposição ao setor formal, ou ao que escapa aos domínios do Estado sendo que muitas vezes o próprio Estado é agente produtor de informalidades (GONÇALVES; BAUTĖS; MANEIRO, 2018). A pandemia de COVID-19 evidencia a hipótese de que não há uma separação clara entre formal e informal, ambos os campos são interdependentes, e suas relações não abrangem apenas questões referentes à economia, sim a toda a dinâmica urbana - mobilidade, moradia, infraestrutura, assistência social e, evidentemente nos últimos tempos, a saúde pública.

Dessa forma, se faz necessário refletir sobre a dimensão política da informalidade, compreender que a mesma não se refere apenas ao que se insere ou se excluido aparato de controle 
do Estado, mas a determinadas lógicas urbanas, práticas locais e sociais, meios de comunicação, dentre outras. Tal visão ampliada da informalidade baseia o diálogo proposto entre Moçambique e Brasil, com estudos sobre as cidades de Pemba e Duque de Caxias. Em ambos os países, a informalidade urbana constitui um aspecto característico das populações que encontram sustento para suas familias em atividades que se tornariam inviáveis diante das recomendações internacionais sobre a COVID-19. O conhecimento das realidades urbanas - entre semelhanças e diferenças em Moçambique e Brasil - orienta o diálogo que propõe evidenciar as fragilidades das políticas públicas adotadas no contexto, que conduzem a situações problemáticas com impactos sentidos de diferentes formas nos espaços urbanos.

\section{O CONTEXTO DE MOÇAMBIQUE NA PANDEMIA DE COVID-19}

Apesar de o IDH em países africanos registrar crescimentos, e da tendência à diminuição da pobreza nos últimos anos, 544 milhões de pessoas, ou 54\% da população de África ainda vive na pobreza (AFDB; OECD; UNDP, 2017). De acordo com o Banco Mundial(2017), fatores como urbanização acelerada, baixo investimento em infraestruturas e serviços básicos, insalubridade, falta de alimentos e desarticulação entre educação e crescimento econômico, são fatores que causam e agravam a pobreza nos países. Ademais, o elevado desemprego faz com que mais de $80 \%$ da população economicamente ativa entre jovens e mulheres encontre sustento no setor informal, geralmente pouco remunerado (AFDB, 2013)

De acordo com relatório elaborado pela Organização Internacional do Trabalho(ILO, 2019), o PIB de Moçambique distribui-se em: 22,5\% agricultura, pecuária epesca; 12,2\% transportes, armazenamento, informação e comunicação; $11,3 \%$ comércio e serviços; $8,6 \%$ indústria; $6,7 \%$ aluguel de imóveis; $7,5 \%$ educação e 31,2\% outros setores. Desse total, $40 \%$ do PIB de Moçambique provém do setor informal (BANCO MUNDIAL, 2019). O país possui $57,6 \%$ da população como força de trabalho ativa, sendo que destes, $84,6 \%$ trabalham em condições precárias. Tal força de trabalho é dividida em $66,8 \%$ no setor primário, $4,5 \%$ no secundário, $12,9 \%$ no terciário e $15,8 \%$ em outras atividades (INE, 2017).

Os setores e atividades não registrados nas estatísticas oficiais são formas de trabalho denominadas ganho-ganho, ou seja, ações cotidianas sem qualquer vínculo empregatício realizadas para o sustento diário (carregar compras, lavar carros, entregar alimentos, vendas em geral, etc.), suportadas majoritariamente pelo gênero feminino. Neste contexto, mais de $95 \%$ das mulheres em Moçambique exercem atividades domésticas, agricultura, comércio, serviços de beleza, entre outras atividades não legitimadas pela lei, agravando, deste modo, a desigualdade de oportunidades entre os 
gêneros. A informalidade urbana é uma das principais características dos modos de estar e viver das cidades dos países da África subsaariana, abrangendo hábitos, tradições e costumes de populações que enfrentam a pobreza, conflitos políticos armados e calamidades naturais.

A maior parte da população de Moçambique se concentra em áreas rurais (66,6\%) (INE, 2017), e a maior parte da força de trabalho está no setor primário. Contudo, grande parte da população rural migra diariamente para as cidades em busca de trabalho, de forma que o setor terciário é o que tem maior participação no PIB, sendo as atividades relacionadas a comércios e serviços, em sua maioria, informais e concentradas nas áreas urbanas. Ainda de acordo com o INE, Moçambique possui uma taxa de dependência de 99,5\%, ou seja, a cada 100 pessoas, cerca de 99 dependem de outras para suportar as despesas.A desigual disponibilidade de serviços básicos, especialmente em saúde e educação, saneamento básico, renda mensal e ausência de emprego sustentável estão na raiz desta disparidade econômica.

Os anos que se seguiram à independência de Moçambique foram caracterizados por várias crises políticas, econômicas e socioculturais, que fizeram com que cidades e vilas passassem a receber contingentes populacionais de todas as regiões - rurais e urbanas - 0 que se traduz no que Araújo (2003) chama de "explosão urbana", movimento em que as pessoas, em busca de proteção e bem-estar, foram ocupando os espaços deixados pelos colonizadores.

Essas turbulências aconteceram em um momento em que o país não estava preparado economicamente para dar respostas às demandas geradas pela urbanização, como infraestruturas, serviços básicos e empregos. 0 crescimento populacional não foi acompanhado pelo planejamento urbano, econômico, social ou cultural, o que contribuiu para a degradação das cidades, proliferação de atividades informais como fonte de sobrevivência da população, tornando mais visíveis as desigualdades sociais (ARAÚJO, 2003).

Em relação às condições de moradia da população, de acordo com o último censo(INE, 2017), entre os materiais das coberturas das residências prevalece o capim $(50,8 \%)$ e o zinco $(44,1 \%)$; entre as paredes, $30,7 \%$ são de adobe, $22,3 \%$ de paus maticados e $18,8 \%$ de blocos de cimento; nos pisos prevalece a terra batida (42\%) e o cimento $(34,4 \%)$. Em relação à infraestrutura, as casas têm acesso à energia elétrica, em sua maioria através de pilhas (41\%), sendo que as redes elétricas públicas atendem somente $22,2 \%$ das casas; já referente ao abastecimento de água, $32,2 \%$ das casas se utilizam de poços não protegidos, $15,8 \%$ de poços protegidos e com bombas e apenas 12,1\% têm acesso à rede de água.

Estima-se que $51,3 \%$ da população bebe água de fonte não segura. É nesse sentido que a maioria dos autores entende que a situação da pobreza do maior número de famílias moçambicanas torna não aplicáveis as recomendações da OMS no enfrentamento ao novo coronavírus. Vale lembrar 
que a taxa de fecundidade em Moçambique é de 5,2 filhos por mulher, e que o número médio dos agregados familiares é de 4,4, ou seja, em locais insalubres e escassos de infraestrutura, vivem geralmente muitas pessoas juntas.

Em Moçambique, a eclosão da pandemia escancarou a questão da segregação estrutural, física, social e espacial da população. Mais de $47,4 \%$ da população vive em palhotas (casas de palha), sem o devido acompanhamento de infraestruturas e saneamento. A informalidade perpassa, portanto, esse contínuo cruzamento rural-urbano presente no país. Em assentamentos desordenados e não planificados, as populações enfrentam um drama existencial entre morrer de fome em casa nas condições de insalubridade e à espera que o vírus lhes atinja, ou encontrarem a morte ao saírem de casa para trabalhar(JORNAL TXOPELA, 2020a).

Para evitar a propagação da COVID-19, o governo de Moçambique produziu alguns instrumentos legais como medidas de prevenção e combate à pandemia: fechamento de escolas e locais públicos, elaboração de métodos padronizados de higiene, distanciamento social em locais de aglomeração, encerramento e diminuição de atividades comerciais, proibição de eventos sociais e de lazer, suspensão de pagamento de impostos e taxas, rotatividade laboral, criação de unidades sanitárias equipadas com leitos para atendimento e internação, e instalação de tendas e unidades sanitárias para testagem da temperatura (ARMANDO, 2020).

Devido à insuficiência das infraestruturas de saúde, o INS (Instituto Nacional de Saúde) orientou sobre a reserva de instalações para pacientes em estado grave, enquanto a maior parte da população foi sensibilizada para o tratamento domiciliar. No reforço a essas medidas, foram criadas estratégias com a Polícia da República de Moçambique (PRM) para a vigilância de pessoas que violassem os decretos da presidência, com destaque para a atuação nos lugares de aglomeração.

Entretanto, a maioria das medidas tomadas foi ineficaz. A pandemia não foi tida como prioridade em Moçambique devidoàs dramáticas conjunturas pelas quais o país passa, como a guerra, os desastres naturais, a pobreza, a precariedade das casas e da infraestrutura urbana, a ausência de seguridade social e a informalidade do trabalho, que coloca as pessoas em constante circulação em busca de sustento, tanto nas cidades e províncias de Moçambique quanto em países vizinhos. A rápida propagação e transmissão comunitária da COVID-19 registra-se nas províncias de Maputo, Nampula, Zambézia e na cidadePemba.

\subsection{Pandemia e outras catástrofes em Pemba}

Cabo Delgado registra um índice de pobreza de 38\%, abaixo da média nacional, de 54\%(COOPERACIÓN ESPAÑOLA, 2014). Entretanto, a informalidade urbana na província, assim 
como em toda a Moçambique, é histórica, tendo como marco inicial a guerra civil de 1977, quando as populações de diversos distritos buscaram refúgio nas regiões urbanizadas. Nos últimos treze anos, o movimento populacional em Pemba - capital da província, centro portuário e polo políticoadministrativo, industrial, comercial, cultural e turístico - registra crescimentos constantes.

Fatores como a descoberta de petróleo no Rio Rovuma ou a insurgência islâmica, geram deslocamentos populacionais para a cidade em busca de trabalho e segurança. A pobreza e a situação de vulnerabilidade dos moradores de Cabo Delgado são condições que favorecem o estabelecimento de grupos radicais na região, que promovem ataques violentos desde 2017 (MATIAS, 2019). Atualmente, a emergência da COVID-19, acaba, paradoxalmente, causando também um grande deslocamento das pessoas em busca de trabalho diante de um cenário econômico instável.

Com a chegada da pandemia a Pemba, as polícias nacionais e locais concentraram suas operações nos mercados informais, como barracas de venda de comida ou bebidas alcoólicas. Neste sentido, diversos comércios foram destruídos nas vias públicas, sem que qualquer apoio fosse dado aos comerciantes. Os comerciantes, que dependem da venda de produtos diversos para o ganho diário, preocupam-se com a propagação do vírus, mas também com a possibilidade de terem seu sustento tomado pela polícia (SIC NOTÍCIAS, 2020).

Um Inquérito Soroepidemiológico realizado pelo INS em agosto aponta que na cidade de Maputo (capital de Moçambique), todas as faixas etárias e todos os grupos profissionais estavam afetados pela COVID-19. Entretanto, os grupos que, de alguma forma, ligavam-se ao trabalho nos mercados, apresentavam um índice maior de contaminação, o que mostra que os comerciantes são mais vulneráveis à doença (MATIAS, 2020). Nesta rusga, a maior parte da população interpelada pela polícia nas atividades informais foi detida em todo o país.

Na província nortenha de Nampula, por exemplo, cinquenta crianças foram interpeladas por praticarem atividades de comércio nas ruas, tendo sido levadas a instalações policiais. De acordo com Zacarias Nacute, porta voz da PRM em Nampula, este não seria o momento de deixar crianças ocuparem as ruas, incentivando os pais e encarregados a serem vigilantes e não permitirem que seus filhos saíssem de casa(LUTXEQUE, 2020). Tal declaração não leva em conta o fato de que no país, mais de 11.000 agregados familiares de quatro a dez pessoas são chefiados por crianças de 12 a 14 anos (INE, 2017), o que lhes impõe trabalhos informais como vendedores de produtos, apoiantes de bagagens nos mercados ou empregados domésticos como meio de sustento do dia a dia. A refletir, a ação da polícia, embora amparada pelo 'estado de emergência', configura uma violação dos direitos humanos.

Em conversas informais feitas por telefone com moradores, comerciantes, taxistas e vendedores ambulantes de Pemba, sobre o nível de reconhecimento dos riscos adjacentes à exposição 
em ambientes de aglomeração, os entrevistados apontaram o fato de o Estado violar os direitos dos pobres ao fazer cumprir as normas das instituições internacionais. Apesar de reconhecerem a relevância de ações como a higienização das mãos, apontam que as medidas de isolamento necessitariam ser acompanhadas por um apoio financeiro aos trabalhadores sem seguridade social, 0 que não aconteceu.

Um outro aspecto do desajustamento das medidas de prevenção apontado nas entrevistas, foram as condições de saneamento precário nos mercados informais de Pemba, que não passaram por qualquer reforma ou adequação, sequer receberam algum auxílio para tal; enquanto que supermercados, que atendem uma minoria mais rica, tiveram condições de realizar reformas e ajustes para melhor higienização das mãos e dos produtos. Para a presente pesquisa, esses fatos são claros sinais de desarticulação entre as imposições legais e as condições socioeconômicas de vivência urbana em Pemba.

O trabalho informal representa a maior parte das atividades econômicas urbanas de Pemba, abrangendo principalmente pequenas empresas e trabalhadores por conta própria. 0 setor terciário predomina, destacando-se o modelo de flexibilização com trabalhos menos remunerados, como operários, latoeiros, trabalhadores da construção civil, ferreiros e carpinteiros. A informalidade é agravada pelos baixos níveis de escolaridade da população. Vale destacar também o trabalho doméstico, suportado na maioria das vezes por mulheres solteiras e com filhos, que realizam atividades de limpeza, alimentação, cuidados com a casa e com as crianças. Por fim, a própria vida das cidades em Moçambique é caracterizada por trabalhos como vendas e revendas de produtos por ambulantes, lavagem de carros, entre outras.

Durante 0 ano de 2020, apesar de diminuídas, as atividades informais mantiveram-se muito presentes em Pemba, mesmo diante de restrições governamentais, controle e repressão policiais. Essa continuidade da movimentação nas ruas se deve ao fato de os trabalhadores não terem recebido nenhum tipo auxílio financeiro, o que impossibilitou que os mesmos tivessem a opção de parar de trabalhar.

A presença da polícia nessa dinâmica foi relevante, pois grande parte dos vendedores, incluindo crianças, perderam seus sustentos. Anacleto (2020a) aponta que, apesar da ação policial, muitas crianças e adolescentes permanecem nas ruas para ajudar no sustento familiar. Como abordado anteriormente, a conjuntura de Pemba impossibilitou que a pandemia fosse o foco das ações do poder público.

No mês de outubro, por exemplo, as Forças de Defesa e Segurança moçambicanas anunciaram a morte de mais de cem terroristas em Cabo Delgado (ANACLETO, 2020b), o que demonstra a intensidade dos conflitos armadosno território. Além do terrorismo, em 2019 a região foi 
assolada pelo ciclone Keneth, que desalojou muitas famílias de suas residências, as colocando em disputa por espaços nas cidades em busca por alimentos (CÁRITAS PORTUGUESA, 2020).

A pandemia causou impactos relevantes diante deste já tão complexo cenário. Como demonstrado, houve diminuição dos empregos, sobretudo os informais, por conta dos decretos de paralisação e operações policiais. Os transportes das periferias para as áreas centrais tiveram seus fluxos diminuídos, afetando o comércio ambulante e a população de baixa renda que teve seu deslocamento limitado. Vendedores e pequenos empresários perderam clientes e receitas, ao tempo que produtos de primeira necessidade tiveram seus preços elevados. Pessoas deslocadas por conta da guerra concentraram-se em residências de familiares ou conhecidos, aumentando o risco de contaminação por aglomeração em ambientes compartilhados.

Como último ponto de análise, vale apontar que, diante de tantas crises - bélica, natural, econômica, social, política e empregatícia - as cidades de Moçambique contam com importantes iniciativas comunitárias: o Conselho Nacional da Juventude fornece materiais para identificação, demarcação e reassentamento de construções precárias; a Organização da Juventude de Moçambique e o Movimento Democrático de Moçambique recolhem doações em diferentes bairros para distribuição (JORNAL TXOPELA, 2020b); a Comunidade Islâmica distribui alimentos para famílias vulneráveis (GLOBAL, 2020); a Cáritas Diocesana de Pemba contribui com ações educacionais para pessoas em condições de vulnerabilidade (CÁRITAS PORTUGUESA, 2020); a Universidade Pedagógica e a Universidade Rovuma produzem álcool gel para distribuição nas comunidades (TV DE MOÇAMBIQUE, 2020); e o Ministério das Mulheres em Ação atende mais de 1.500 pessoas sem fontes de rendimento, sobretudo mulheres solteiras com crianças (MGCAS; INAS, 2020).

Entidades internacionais também têm um destacado papel no contexto, como: o Programa Mundial de Alimentação (ONU, 2020); o Médicos sem Fronteiras (MSF, 2019); o Comitê Internacional da Cruz Vermelha, que em parceria com a OMS, o UNICEF e o governo moçambicano, anunciou a entrega do maior centro de tratamento de COVID-19 do país em Pemba, com capacidade para até 400 pacientes(MUNDO AO MINUTO, 2020); e a Organização Internacional de Migrações, que faz o registro de todosos migrantes, prestando socorro, atendimentos de saúde e oferecendo kits básicos, como tendas, colchões e mantas (DEUTSCHE WELLE, 2020c). Tanto em Pemba quanto em diversas cidades de Moçambique e de África, a solidariedade é um fator social determinante para o cuidado com a vida das pessoas, sobretudo perante tantas dificuldades. 


\section{REFLEXOS DA PANDEMIA DE COVID-19 NO BRASIL}

De dimensões continentais, o Brasil possui uma grande diversidade territorial, cultural, geográfica, econômica e demográfica. Dentro do escopo do presente texto, a comparação em muitos âmbitos específicos com Moçambique não conduziria a resultados relevantes, dadas todas as disparidades apontadas. O que se propõe, portanto, é um diálogo que tenha a questão da informalidade diante do enfrentamento à pandemia de COVID-19 como linha guia, apoiado na análise de fatores gerais e das cidades de Pemba e Duque de Caxias.

O Brasil possui $45,4 \%$ da população na força de trabalho. Entre a população ocupada, estima-se que 34,57\% trabalhem na informalidade (PNADC, 2020). A representatividade do setor terciário no PIB brasileiro sempre foi muito relevante, chegando a 73\% em 2018(BRASIL, 2019), sendo o comércio o grande responsável por esse avanço. No início de 2019, o IBGE calculava uma tímida queda na taxa de desocupação, ao mesmo tempo que registrava um crescimento recorde nas taxas de informalidade (IBGE NOTÍCIAS, 2019). Já em 2020, com a pandemia de COVID-19, a taxa de desemprego alcançou números recordes (14,4\% em agosto). De acordo com o Nexo Jornal (2020), foram quase nove milhões de empregos perdidos até junho, sendo que os empregos informais, apesar de serem menos numerosos e os com menor remuneração, foram os mais atingidos.

Oliveira e Ribeiro (2020) apontam que a chegada da COVID-19 ao Brasil impôs novos obstáculos à retomada de crescimento de empregos que já se encontrava desfavorável desde 2014 com o início da crise econômico-política. Os dados apontam que a pandemia atinge com mais força 0 setor terciário, o que é grave para cidades que têm sua economia fortemente dependente de comércios e serviços.

A desigualdade econômica do Brasil, assim como a questão da informalidade, reflete-se na urbanização das cidades. De acordo com Silva (2012), a partir da década de 1970, com a desconcentração da produção industrial brasileira, houve um significativo aumento do fluxo migratório para as metrópoles. Esse crescimento produz relevantes transformações urbanas, como expansão territorial, aumento das periferias, formação de novas centralidades, aumento da desigualdade socioespacial, fragmentação urbana, ocupações e favelizações, formação de vazios urbanos alvos de especulação imobiliária, insuficiência das redes de infraestrutura urbana e dos sistemas de transporte coletivo. Tais problemas inserem-se em um modelo de planejamento que não leva em consideração a questão da justiça social e que se pauta pela razão neoliberal de mercantilização do uso do solo urbano, desprezando sua função social.

Em relação à infraestrutura urbana oferecida aos domicílios, o Brasil apresenta números relativamente bons (PNADC, 2019): 85,5\% têm a rede geral de distribuição de água como principal 
forma de abastecimento; 99,5\% possuem energia elétrica proveniente da rede geral; $84,4 \%$ têm o lixo coletado diariamente e o dado mais crítico se refere à coleta de esgotamento sanitário, sendo que $68,3 \%$ das casas são ligadas à rede geral ou possuem fossa séptica ligada à rede.

Sabe-se que as habitações mais afetadas pela falta de infraestrutura urbana encontram-se nas regiões periféricas (favelas e bairros irregulares), justamente as áreas que historicamente apresentam condições mais precárias de trabalho, informalidade, maior dependência do transporte público e menor acesso a serviços de saúde. A pandemia de COVID-19, portanto, apesar de ter sido vista, em um primeiro momento, como uma doença que atingiria as parcelas mais ricas da população, pelo contrário, por conta das condições das cidades brasileiras e suas desigualdades, afeta com muito mais força os mais pobres(LUPION, 2020).

A postura do Brasil frente à crise causada pela pandemia de COVID-19 será aqui analisada sob três aspectos que se relacionam entre si: 1) as ações efetivas do poder público (federal, estadual e municipal); 2) posicionamento errático e desarticulado dos governantes, sobretudo do presidente da república, que influencia negativamente o enfrentamento à pandemia em todos os níveis; e 3) o comportamento da população frente às medidas e discursos oficiais, o que passa pela questão da informalidade e da desigualdade socioespacial nas cidades.

As primeiras ações do governo federal brasileiro frente à pandemia foram as repatriações de brasileiros residentes em Wuhan (BRASIL, 2020a) e o monitoramento de países onde o vírus se espalhava com mais velocidade $(G 1,2020)$. 0 governo federal também tomou diversas ações no que diz respeito ao fortalecimento de sua estrutura de saúde pública: reforços na atenção primária, repasses financeiros para estados e municípios, contratação e convocação de pessoal, aquisição de equipamentos como respiradores mecânicos e materiais de proteção como máscaras e luvas, financiamento e construção de hospitais de campanha, compra e distribuição de kits de testagem, dentre outras (BRASIL, 2020b).

O Ministério da Saúde ainda estabeleceu os critérios de isolamento social e quarentena, o que foi importante para os decretos municipais e estaduais de interrupção de atividades e serviços não essenciais. 0 Brasil também passou a integrar grupos nacionais e internacionais de desenvolvimento de medicamentos, tratamentos e vacinas contra a COVID-19 (PINTO, 2020).

A medida mais relevante, contudo, foi o programa de auxílios emergenciais para desempregados, trabalhadores informais, pessoas com baixa renda ou microempreendedores individuais (CAIXA, 2020). Vale apontar, todavia, que o programa demorou tempo demais para ser estruturado e implementado, teve vários problemas nos cadastramentos(EXTRA, 2020), denúncias de fraudes (AGÊNCIA BRASIL, 2020), geração de filas e aglomerações em agências bancárias (AGORA, 2020), e o valor, que inicialmente foi de $R \$ 600,00$ de abril a agosto, diminuiu para $R \$ 300,00$ de 
setembro a dezembro (ROUBICEK, 2020b). O auxílio foi fundamental para muitas famílias, mas sofreu com a ausência de um planejamento estratégico.

As ações governamentais federais, estaduais e municipais em relação à pandemia foram desarticuladas e imersas em disputas de narrativas políticas, interesses ideológicos e eleitoreiros. A postura do governo federal, centrada na figura do presidente da república, paradoxalmente, contrariou por diversas vezes as recomendações de seu próprio Ministério da Saúde. Desde desinformação propagada por membros do governo ou por agências da burocracia estatal (CHADE, 2020), passando por pronunciamentos oficiais do presidente por rádio, internet e TV, ou lives informais do mesmo por redes sociais, o que se viu foi uma postura negacionista da real gravidade da situação pandêmica no país (VANNUCHI, 2020).

O presidente ainda participou de eventos públicos com aglomerações, na maioria das vezes não utilizando máscara, e suas falas sempre foram contrárias ao isolamento social (BENITES; BETIM, 2020). Vale destacar que dois ministros da saúde foram desligados de seus cargos durante 0 processo de enfrentamento à pandemia por motivos políticos (BITTAR; CHALUB, 2020). Tais dissonâncias entre discurso e prática provocam instabilidade na sociedade civil, dada a polarização política que o país vive desde 2014. Enquanto uma parcela da sociedade pregava o fim do isolamento social para que a economia não fosse prejudicada, outra parcela exigia medidas rígidas e racionais para um maior controle da doença.

Nesse contexto, o governo não soube se posicionar de maneira assertiva, embasada cientificamente ou com responsabilidade social. Talvez o maior exemplo de tais desalinhos do Brasil frente à COVID-19 tenha sido a produção, distribuição, defesa e uso irrestrito de medicamentos que, comprovadamente, são ineficazes contra o novo coronavírus, como a cloroquina (LEMOS, 2020). 0 medicamento foi apresentado ao público, sobretudo aos seguidores mais fiéis do presidente, como solução para o problema da pandemia, mesmo sem comprovação científica de sua eficácia, o que acaba desestimulando as pessoas de manterem suas exaustivas situações de isolamento e cuidados constantes, contribuindo para a generalização do caos nas cidades.

A população brasileira, diante da falsa dicotomia entre saúde e economia e da polarização política em ano de eleições municipais, oscilou entre períodos de maior e menor paralisação das atividades nas cidades, convivendo com elevados números de casos e mortes, lotação de leitos de hospitais, falta de equipamentos e materiais, além de indefinições e incertezas quanto às medidas a serem seguidas e recomendações a serem respeitadas.

Sobretudo a população mais pobre foi mais afetada, tanto por empregadores que não foram suficientemente responsáveis com a saúde de seus funcionários, pautados pelo discurso antiisolamento do presidente, quanto pela impossibilidade de interromper seus trabalhos por questões 
financeiras, ou mesmo a impossibilidade de seguir corretamente todas as medidas de segurança pelas condições de suas moradias ou pela lotação dos transportes públicos.

Diante de todos esses impasses, um evento chama a atenção por seu caráter de enfrentamento à precarização do trabalho no Brasil. 0 'Breque dos Apps' foi o maior movimento de pessoas em trabalho informal da história do país. Coordenado por entregadores de comida por aplicativos (IFood, UberEats, Rappi), o breque reivindicou melhores condições de trabalho e suporte por parte das empresas como: aumento nas taxas de entrega, fim de bloqueios indevidos, seguro para roubos e acidentes, licenças para entregadores infectados e distribuição de EPIs (SILVA, 2020).

A Justiça do Trabalho determinara em janeiro que a relação entre aplicativos e entregadores não poderia ser considerada vínculo empregatício, contrariando o Ministério Público do Trabalho que pedia a contratação pelo regime de CLT de todos que prestavam serviços de entrega para as plataformas. O Breque dos Apps é um movimento importante de resistência diante da flexibilização neoliberal das relações de trabalho que cresce em todas as cidades brasileiras, fazendo com que a informalidade seja encarada como o "novo normal" nos modos de vida, sobretudo das populações mais pobres.

\subsection{Duque de Caxias e a reverberação do discurso anti-ciência}

Duque de Caxias localiza-se na Baixada Fluminense, Região Metropolitana do Rio de Janeiro. 0 desenvolvimento econômico e crescimento populacional da cidade se intensificou nos anos 1960 com a implantação da Refinaria Duque de Caxias e outras empresas petrolíferas. A cidade apresenta problemas no saneamento básico, estimando-se 300 mil habitantes sem acesso a água potável. Também há desigualdade na distribuição de infraestruturas, educação, renda e trabalho. Considerando que mais de $37 \%$ da população do município tem uma renda per capita de aproximadamente $\mathrm{R} \$ 500,00$ (IBGE, 2020a), e sendo o salário médio dos trabalhadores formais, que representam cerca de $18 \%$ da população, de $R \$ 3.100,00$, têm-se por volta de 400 mil pessoas trabalhando na informalidade.

O prefeito da cidade apresenta um discurso contrário ao isolamento social e ao fechamento das atividades comerciais, tanto que a cidade foi uma das últimas da região metropolitana a decretar paralisações. Mesmo depois de ter sido diagnosticado com COVID-19 e internado em um hospital na região nobre da capital do estado, o prefeito, baseado em um discurso fundamentalista e alinhado aos posicionamentos do governo federal, insistiu em suspender apenas aulas e feiras livres, deixando opcional a igrejas e comércios a abertura ou fechamento, contrariando recomendações 
científicas e decretos dos municípios vizinhos. "Foi orientação, desde a primeira hora, manter as igrejas abertas porque a cura virá de lá, dos pés do Senhor", afirmou o prefeito em vídeo (CRUZ, 2020).

No dia 26 de março, com a suspensão de atividades escolares, o prefeito fechou uma parceria com um aplicativo fintech para o pagamento do Auxílio Merenda. Através da carteira digital PicPay, a prefeitura pagaria $\mathrm{R} \$ 50,00$ mensais por aluno da rede municipal de educação, estimando alcançar cerca de 70 mil estudantes.

Com a condição de criar gratuitamente uma conta no aplicativo, todos teriam direito ao auxílio. Dois meses depois, pais e alunos reclamavam sobre o não recebimento do valor, houve relatos de cancelamento do depósito por parte da prefeitura em algumas contas, outros casos afirmavam o recebimento de quantias menores que a acordada $(R \$ 2,51)$. 0 auxílio financeiro, portanto, não foi realizado com um planejamento que permitiu seu funcionamento pleno(REGUEIRA, 2020).

Ainda no mês de março, a taxa de letalidade por COVID-19 na cidade era maior que as médias nacional e mundial (NORONHA, 2020).Os números elevados eram relacionados à baixa testagem, realizada apenas em pessoas com sintomas graves. Entretanto, especialistas estavam convictos de que o número de infectadoscresceriaexponencialmente, de forma que em 01 de abril, 0 município não registrara nenhuma morte, e quinze dias depois já era o segundo maior em óbitos e o quinto em número de casos (ESTADÃO, 2020).A falta de fiscalização, conscientização e responsabilidade por parte do poder público, dificultou a execução dos decretos sobre isolamento e fechamento.

O primeiro caso na cidade se confirmou em 23 de março (ALVES, 2020a); a primeira morte em 31 do mesmo mês - tendo sido confirmada no dia 02 de abril, quando a prefeitura municipal divulga boletim extraordinário decretando fechamentos e restrições ao comércio por 15 dias (TORRES, 2020b). Importante ressaltar que templos religiosos não se enquadraram entre os locais a serem fechados. No final de abril, Duque de Caxias apresentava 400 casos confirmados e 70 óbitos, e a imprensa noticiava a acumulação de cadáveres em um corredor próximo ao necrotério de um dos hospitais da cidade (O GLOBO, 2020).

No dia 04 de maio, a cidade inaugura o Hospital Municipal para Tratamento de COVID-19 com 250 leitos de CTI (O FLUMINENSE, 2020). No dia 25 do mesmo mês, alegando grande disponibilidade de leitos na cidade e um prejuízo de 100 milhões nos cofres públicos, o prefeito decide abrir o comércio, afirmando não ter "bola de cristal" para saber qual impacto tal decisão teria sobre a população (BARRETO FILHO, 2020). Nesse dia, o índice de mortalidade na cidade era de 15,3\%, com estudos afirmando uma possibilidade de subnotificação até seis vezes maior.

No dia 08 de junho, mesmo com a suspensão do decreto do prefeito, comerciantes começam a reabrir seus estabelecimentos, já que não havia fiscalização. Nesse mesmo dia, a cidade 
aderiu ao plano de flexibilização do governo estadual, com funcionamento de comércios e bares (TORRES, 2020a). Dois dias depois a cidade atingiria quase 2.000 casos confirmados e 310 óbitos. No dia 15 de junho a prefeitura inicia um projeto de testagem rápida em massa, havendo testado até tal data mais de 30 mil pessoas. 0 número total de testes realizados, cerca de quatro meses após o início da pandemia, não representava sequer $10 \%$ da população. Diante todo este cenário, a cidade viu sua taxa de óbitos aumentar em 143\% (ALVES, 2020b). Duque de Caxias, até o início de novembro, apresentara um total de 11.044 casos confirmados e 789 mortes (RIO DE JANEIRO, 2020).

A tabela que se segue apresenta um quadro de síntese de dados gerais de Moçambique, Pemba, Brasil e Duque de Caxias. Importante observar a diferença significativa nos dados que apontam a extensão territorial e o número de habitantes entre os países e cidades, ao mesmo tempo que se destaca a proximidade entre os valores de densidade populacional entre as mesmas, fator determinante na análise da pandemia por conta da forma de disseminação da COVID-19. A seguir, desenvolve-se o diálogo entre Moçambique/Pemba e Brasil/Duque de Caxias, levando-se em conta os dados apresentados, os contextos analisados e outros fatores relevantes.

Tabela 1: Síntese Moçambique-Pemba / Brasil-Duque de Caxias. Dados retirados dos institutos nacionais de estatística.

\begin{tabular}{|c|c|c|c|c|}
\hline & Moçambique & Pemba & Brasil & Duque de Caxias \\
\hline Independência & 1975 & - & 1822 & 924.624 \\
\hline População & 27.909 .798 & 200.529 & 211.755 .692 & $19,78 \mathrm{hab} . / \mathrm{ha}$ \\
\hline Densidade pop. & $0,35 \mathrm{hab} . / \mathrm{há}$ & $19,65 \mathrm{hab} . / \mathrm{ha}$ & $0,25 \mathrm{hab} . / \mathrm{ha}$ & $467,319 \mathrm{~km}^{2}$ \\
\hline Território & $801.590 \mathrm{~km}^{2}$ & $102 \mathrm{~km}^{2}$ & $8.510 .295,914 \mathrm{~km}^{2}$ & 0,711 \\
\hline IDH & 0,466 & - & 0,761 & - \\
\hline PIB & US\$ 14,934 bi & - & US\$ 1,84 tri & - \\
\hline PIB per capita & US\$ 535,08 & - & $0,6399,25$ & 11.044 \\
\hline Gini & 0,54 & - & 5.590 .025 & 789 \\
\hline $\begin{array}{l}\text { Casos COVID-19 } \\
\text { Início nov. 2020 }\end{array}$ & 13.768 & 926 & 161.106 & \\
\hline $\begin{array}{l}\text { Mortes COVID-19 } \\
\text { Início nov. 2020 }\end{array}$ & 99 & 2 & & \\
\hline
\end{tabular}

4 DIÁLOGO ENTRE MOÇAMBIQUE E BRASIL: informalidade e pandemia

A escolha de Moçambique e Brasil como estudos de caso do presente trabalho baseia-se na grande presença da informalidade não somente na economia de tais países, mas nos modos de vida da população urbana e da própria lógica de desenvolvimento das cidades. 0 fator determinante para a escolha das cidades analisadas de cada caso foi a densidade populacional sendo de 19,65 
hab./ha em Pemba e 19,78 hab./ha em Duque de Caxias. Para densidades próximas, a comparação entre ações governamentais, comportamentos das populações e dados referentes à pandemia, embasam-se de maneira mais contundente, apesar das tantas diferenças conjunturais já apontadas.

A comparação simples dos dados levantados (indicados na tabela 1) não conduz a conclusões assertivas no que se refere ao impacto da COVID-19 em cada caso estudado. Sabe-se que a maioria dos países que apresentaram posturas efetivas para a diminuição do espalhamento da doença, realizaram programas de testagem em massa com rastreamento de contágios e quarentenas para suspeitos. É válido, portanto, analisar também os dados referentes aos testes realizados em Pemba e Duque de Caxias.

De acordo com o INS (2020), até o dia 10 de novembro, haviam sido realizados 204.650 testes em Moçambique, o equivalente a aproximadamente $0,733 \%$ da população. Os mais recentes boletins diários divulgados apontam que a província que mais realiza testes no país é a de Maputo Cidade, ou seja, a tendência é que a testagem em Cabo Delgado, consequentemente, em Pemba, siga a estimativa do país e encontre-se abaixo de $1 \%$ da população.

Já o Brasil, de acordo com dados do Ministério da Saúde, havia realizado até o final do mês de outubro, mais de 4,5 milhões de testes tipo PCR (o modelo mais eficaz), totalizando pouco mais de 2,16\% da população (o número seria um pouco maior se incluídos outros tipos de testes)(PINHEIRO; RIOS; LIMA, 2020). Em Duque de Caxias, apesar do programa de testes rápidos em massa, a ação não é combinada com uma estratégia de rastreamento de contágios com controle de quarentenas.

Há que se apontar, portanto, que os números oficiais de casos e óbitos por COVID-19 em Moçambique e Brasil não são confiáveis o suficiente para se ter uma visão geral do impacto da pandemia em ambos os casos. Sabe-se que quanto mais testes são realizados, maior é o número de detecção de casos, por conta disso, a subnotificação em ambos os países é elevada, dada a quantidade insuficiente de testes que não comunicam um quadro amplo.

Todavia, a disparidade dos números ainda chama muita atenção entre as duas cidades estudadas. Algo que pode explicar tal diferença é o contexto mais amplo da inserção das mesmas nos territórios. Pemba, apesar de ser a capital de Cabo Delgado, não é sequer o distrito mais populoso. A população de Cabo Delgado reside predominantemente em áreas rurais $(83,2 \%)$, e ao se analisar a densidade populacional da província, verifica-se apenas 0,28 hab./ha(INE, 2013).

Já Duque de Caxias encontra-se na Região Metropolitana do Rio de Janeiro, conurbada com várias outras cidades da Baixada Fluminense. A cidade possui uma população predominantemente urbana e insere-se em um estado com densidade demográfica aproximada de 3,65 hab./há (IBGE, 2020b) que se eleva para 17,25 hab./ha ao se considerar somente a região 
metropolitana. Ou seja, em relação a Pemba, Duque de Caxias encontra-se em um contexto urbano, com o qual mantém estreitas relações, muito mais populoso.

Outro ponto a se ressaltar é a proximidade das cidades com aeroportos, visto que o vírus se espalhou entre os países, na maioria das vezes, por voos internacionais. Duque de Caxias encontrase a poucos minutos de distância do Aeroporto Internacional Tom Jobim (Galeão), pelo qual circularam 13,5 milhões de passageiros em 2019 (CASTILHO, 2020); e a menos de uma hora de distância do Aeroporto Santos Dumont (8,9 milhões de passageiros em 2019), na cidade do Rio de Janeiro. Toda a região próxima à capital é um grande polo atrativo de turismo, seja de negócios, lazer ou cultura, o que faz com que o território que envolve Duque de Caxias seja uma área intensamente movimentada em todos os períodos do ano. Já em relação a Pemba, o aeroporto da cidade não é sequer o quarto mais movimentado do país (AEROPORTOS DE MOÇAMBIQUE, 2020).

Em relação a voos internacionais, se comparado ao Aeroporto Internacional de Maputo o maior de Moçambique, distante mais de 2.500 km de Pemba - o Aeroporto de Pemba apresenta um número aproximadamente seis vezes menor de voos. Vale ressaltar, entretanto, que as cidades moçambicanas apresentam um grande fluxo entre si realizado através de automóveis, motocicletas ou mesmo a pé; tais movimentações acontecem entre cidades, zonas urbanas e rurais, distritos, províncias ou mesmo países vizinhos.

0 tráfego interno em Moçambique é um fator tão relevante quanto o movimento aeroportuário na questão da transmissão da COVID-19, pois as fronteiras, mesmo as que foram declaradas fechadas, não apresentaram uma fiscalização rigorosa a ponto de interromper com efetividade as movimentações características das populações.

A presença da informalidade nas cidades estudadas não é um fator de causa direta no espalhamento da COVID-19, mas insere-se em um contexto que - aliado à pobreza, aos modos de vida e a governos socialmente irresponsáveis - compõe um cenário de enorme dificuldade no cumprimento das recomendações hegemônicas. Há um claro paradoxo, portanto, entre as principais orientações de autoridades da OMS para países e cidades no enfrentamento ao novo coronavírus, e as condições socioeconômicas e políticas, sobretudo no sul global, de segui-las.

O trabalho informal e as formas precárias de habitação imprimem um modo de vida às populações que impede que as mesmas tenham sequer a opção de fazer uma quarentena adequada mesmo que por curtos períodos de tempo, pois dependem do trabalho diário para viver, se alimentar e cuidar de suas famílias. Mesmo diante das tentativas de paralisação de atividades nas cidades, com repressão policial, como no caso de Pemba, ou com auxílios financeiros, como no caso de Duque de Caxias, as estratégias de enfrentamento à pandemia falharam em ambos os casos, pois não levaram em consideração nem a informalidade presente nos cotidianos das populações, nem uma série de 
outros fatores, como a espacialidade das residências, os hábitos culturais e domésticos que envolvem a proximidade e o contato entre os corpos, a falta de saneamento básico em muitos casos, e a ausência de um planejamento estratégico, integrado com testagem massiva, ou mesmo sensatez e coerência em discursos oficiais.

\section{CONSIDERAÇÕES FINAIS}

Simoni (2020) reflete que se o novo coronavírus tivesse um DNA, ele portaria "o gene da sociedade urbana". Pondera que a principal forma de combate à pandemia depõe contra o próprio modelo de sociabilidade humana edificada durante o século XX, negando as principais faculdades da vida urbana: a troca, a proximidade, o convívio, o encontro, a concentração e a centralidade, em termos lefebvrianos.

A segregação socioespacial está no cerne das cidades modernas e contemporâneas, "ao mesmo tempo em que o urbano é a concentração de riqueza, ele é também a concentração da pobreza" (SIMONI, 2020). Dentro de uma lógica de rendimento e competição, em meio à mais mortal pandemia dos últimos cem anos, enquanto o esforço dos ricos continua caminhando no sentido da acumulação, o dos pobres mira-se para a sobrevivência.

Muitas das recomendações hegemônicas sobre como lidar com a COVID-19 ignoram especificidades de muitos países do sul global, sobretudo das regiões mais pobres de suas cidades, como a incompetência de governantes, o dificultoso acesso a testes e equipamentos de proteção individual, a desinformação em proporções devastadoras, a violência policial, a inexistência ou insuficiência de mecanismos de auxílio social, as precárias condições de trabalho e a informalidade. Soma-se ainda o fato de que em tais áreas as condições de moradia, infraestrutura e saneamento são impeditivas para o seguimento das medidas ideais, ditadas por autoridades internacionais, nacionais e mesmo locais.

A presente pesquisa demonstrou como a informalidade urbana, mais do que mera questão demográfica ou econômica, se refere à política dos países e cidades estudadas, pois engloba toda uma ideia de sociedade, desde o controle estatal sobre a esfera formal, até suas relações com práticas informais que determinam boa parte dos heterogêneos modos de vida urbana em Moçambique/Pemba e Brasil/Duque de Caxias. Ademais, mostrou-se como os posicionamentos erráticos de governantes em diversas escalas são prejudiciais, sobretudo para as populações mais pobres, dentro de um cenário pandêmico que ainda se faz presente. Neste contexto, apesar da apontada existência de relevantes redes de solidariedade e movimentos de resistência, o estudo revela a importância e a urgência da implementação de políticas públicas integradas, planejadas e que, ao mesmo tempo que abrangentes, 
levem em consideração também especificidades locais, demandas sociais e contextos socioeconômicos.

Enfrentar a lógica do lucro é um grande desafio para quem "vende o almoço para comprar a janta". A pandemia coloca muitaspessoas diante de um novo dilema: sair para trabalhar,se infectar com o risco de morrer ou de infectar pessoas queridas mais vulneráveis; se isolar de alguma maneira, não trabalhar e correr o risco de morrer de fome; ou não sair para trabalhar, ficando em uma casa dividida com outras pessoas, sem condições de higiene e de distanciamento, também no risco de se contaminar de alguma maneira, morrer ou colocar em risco pessoas próximas. Quando não há direito à cidade, viver é uma opção muito cruel.

\section{REFERÊNCIAS}

AEROPORTOS DE MOÇAMBIQUE. Institucional. Disponível em: https://www.aeroportos.co.mz/. Acesso em: 19 nov. 2020

AFDB. Recognizing Africa's Informal Sector. Text. Disponível em: https://blogs.afdb.org/afdbchampioning-inclusive-growth-across-africa/post/recognizing-africas-informal-sector-11645. Acesso em: 18 nov. 2020.

AFDB; OECD; UNDP (eds.). Special theme: Entrepreneurship and industrialisation. Paris: OECD Publishing, 2017.

AGÊNCIA BRASIL. Polícia Federal faz ação contra fraudes no auxílio emergencial. Disponível em: https://agenciabrasil.ebc.com.br/geral/noticia/2020-11/policia-federal-faz-acao-contra-fraudes-noauxilio-emergencial. Acesso em: 19 nov. 2020.

AGORA, S. P. Caixa volta a ter filas do auxílio emergencial. Disponível em: https://agora.folha.uol.com.br/grana/2020/09/caixa-volta-a-ter-filas-do-auxilio-emergencial.shtml. Acesso em: 19 nov. 2020.

ALEXANDER, T. F. Gráfico da semana - A economia informal mundial: extensa mas em declínio. Disponivel em: https://www.imf.org/en/News/Articles/2019/10/30/the-global-informal-economy-large-buton-the-decline. Acesso em: 19 nov. 2020.

ALVES, M. Duque de Caxias confirma primeiro caso de CoronavírusDiário do Rio de Janeiro, 24 mar. 2020a. Disponível em: https://diariodorio.com/duque-de-caxias-confirma-primeiro-caso-decoronavirus/. Acesso em: 19 nov. 2020.

ALVES, M. Caxias passa de 12 mil casos confirmados de covid-19 e Dráuzio Varella chama prefeito de "irresponsável"'Diário do Rio de Janeiro, 2 jul. 2020b. Disponível em: https://diariodorio.com/caxias-passa-de-12-mil-casos-confirmados-de-covid-19-e-drauzio-varellachama-prefeito-de-irresponsavel/. Acesso em: 19 nov. 2020. 
ANACLETO, D. Crianças continuam a vender nas ruas de Pemba apesar das restrições | DW | 22.04.2020. Disponível em: https://www.dw.com/pt-002/crian\%C3\%A7as-continuam-a-vender-nas-ruasde-pemba-apesar-das-restri\%C3\%A7\%C3\%B5es/a-53205528. Acesso em: 18 nov. 2020a.

ANACLETO, D. Moçambique abate mais de cem terroristas em Cabo Delgado | DW | 29.10.2020. Disponível em: https://www.dw.com/pt-002/mo\%C3\%A7ambique-abate-mais-de-cem-terroristas-emcabo-delgado/a-55439223. Acesso em: 18 nov. 2020b.

ARAÚJO, M. G. M. DE. The urban spaces in Mozambique. GEOUSP Espaço e Tempo (Online), v. 7, n. 2, p. 165-182, 17 dez. 2003.

ARMANDO, CARDOSO. Covid-19 avança em Moçambique | História, Ciências, Saúde Manguinhos, 2020. Disponível em: http://www.revistahcsm.coc.fiocruz.br/covid-19-avanca-emmocambique/. Acesso em: 18 nov. 2020.

BANCO MUNDIAL. Greater Maputo : urban poverty and inclusive growth. Text/HTML. Disponível em: https://documents.worldbank.org/en/publication/documents-reports/documentdetail. Acesso em: 19 nov. 2020.

BANCO MUNDIAL. Business Regulations Across European Union 2018. Text/HTML. Disponível em: https://portugues.doingbusiness.org/pt/reports/subnational-reports/mozambique. Acesso em: 18 nov. 2020.

BARRETO FILHO, HERCULANO. Foco de covid reabre comércio e prefeito diz: "Não tenho bola de cristal". Disponível em: https://noticias.uol.com.br/saude/ultimas-noticias/redacao/2020/05/26/focode-covid-reabre-comercio-e-prefeito-diz-nao-tenho-bola-de-cristal.htm. Acesso em: 19 nov. 2020.

BENITES, A.; BETIM, F. Bolsonaro rompe isolamento e vai a atos contra o Congresso em meio à crise do coronavírus | Atualidade | EL PAÍS Brasil. Disponível em:

$<$ https://brasil.elpais.com/brasil/2020-03-15/bolsonaro-rompe-isolamento-e-endossa-atos-contracongresso-em-meio-a-crise-do-coronavirus.html>. Acesso em: 19 nov. 2020.

BITTAR, P.; CHALUB, A. Saída de Nelson Teich do Ministério da Saúde repercute entre deputados - Notícias. Disponível em: https://www.camara.leg.br/noticias/662085-saida-de-nelsonteich-do-ministerio-da-saude-repercute-entre-deputados/. Acesso em: 19 nov. 2020.

BRASIL. A importância do setor terciário para a economia. Disponível em: http://www.mdic.gov.br/index.php/comercio-servicos/a-secretaria-de-comercio-e-servicos-scs/406programas-e-acoes-scs. Acesso em: 19 nov. 2020.

BRASIL. Governo anuncia repatriação de brasileiros que estão em Wuhan, China. Disponível em: https://www.gov.br/pt-br/noticias/justica-e-seguranca/2020/02/governo-anuncia-repatriacao-debrasileiros-que-estao-em-wuhan-china. Acesso em: 19 nov. 2020a.

BRASIL. Saúde vai reforçar capacidade de atendimento para casos de coronavírus. Disponível em: https://www.gov.br/pt-br/noticias/saude-e-vigilancia-sanitaria/2020/03/saude-vai-reforcarcapacidade-de-atendimento-para-casos-de-coronavirus. Acesso em: 19 nov. 2020b.

CAIXA. Auxílio emergencial. Disponível em: https://auxilio.caixa.gov.br/\#/inicio. Acesso em: 19 nov. 2020. 
CÁRITAS PORTUGUESA. Pemba na luta contra o COVID-19 e terrorismoCáritas Portuguesa, 8 abr. 2020. Disponivel em: https://caritas.pt/2020/noticias-noticias/pemba-na-luta-contra-o-covid-19-eterrorismo/. Acesso em: 18 nov. 2020.

CASTILHO, R. Conheça os aeroportos mais movimentados do Brasil. Disponivel em: https://www.melhoresdestinos.com.br/aeroporto-mais-movimentado-brasil.html. Acesso em: 19 nov. 2020.

CHADE, J. Desinformação promovida por Bolsonaro é "agressão à democracia", diz ONU. Disponível em: https://noticias.uol.com.br/colunas/jamil-chade/2020/07/11/desinformacao-promovidapor-bolsonaro-e-agressao-a-democracia-diz-onu.htm. Acesso em: 19 nov. 2020.

COOPERACIÓN ESPAÑOLA. 12 Avaliação intermédia Fortalecimento Institucional do Governo da Província de Cabo Delgado, Moçambique, 2014. Disponivel em: https://www.cooperacionespanola.es/sites/default/files/relatorio_completo_portugues_web.pdf. Acesso em: 18 nov. 2020.

CRUZ, C. Em vídeo, prefeito de Duque de Caxias garante que vai manter igrejas abertas: "A cura virá de lá". Disponivel em: https://extra.globo.com/noticias/rio/em-video-prefeito-de-duque-de-caxiasgarante-que-vai-manter-igrejas-abertas-cura-vira-de-la-rv1-1-24325414.html. Acesso em: 19 nov. 2020. DEUTSCHE WELLE. China tem 1a morte por misteriosa pneumonia viral | DW | 11.01.2020. Disponivel em: https://www.dw.com/pt-br/china-tem-1\%C2\%AA-morte-por-misteriosa-pneumoniaviral/a-51968253. Acesso em: 18 nov. 2020a.

DEUTSCHE WELLE. Covid-19: Moçambique anuncia primeiro caso da doença | DW | 22.03.2020. Disponivel em: https://www.dw.com/pt-002/covid-19-mo\%C3\%A7ambique-anuncia-primeiro-caso-dadoen\%C3\%A7a/a-52880196. Acesso em: 18 nov. 2020b.

DEUTSCHE WELLE, D. Cabo Delgado regista 33 mil deslocados em uma semana, diz organização para migrações | DW | 18.11.2020. Disponível em: https://www.dw.com/pt-002/cabodelgado-regista-33-mil-deslocados-em-uma-semana-diz-organiza\%C3\%A7\%C3\%A3o-paramigra\%C3\%A7\%C3\%B5es/a-55642625. Acesso em: 18 nov. 2020c.

ESTADÃO. Em Duque de Caxias, na Baixada Fluminense, covid-19 matou um em cada cinco infectados - Saúde. Disponível em: https://saude.estadao.com.br/noticias/geral,em-duque-de-caxiasna-baixada-fluminense-covid-19-matou-um-em-cada-cinco-infectados,70003271972. Acesso em: 19 nov. 2020.

ESTADO DE MINAS. Primeiro caso de coronavírus na África subsaariana; Bolsas afundam. Disponivel em: https://www.em.com.br/app/noticia/internacional/2020/02/28/interna_internacional,1124928/primeirocaso-de-coronavirus-na-africa-subsaariana-bolsas-afundam.shtml. Acesso em: 18 nov. 2020.

EXTRA. Beneficiários reclamam de demora para liberação dos saques do auxílio emergencial. Disponivel em: https://extra.globo.com/economia/beneficiarios-reclamam-de-demora-para-liberacaodos-saques-do-auxilio-emergencial-24501888.html. Acesso em: 19 nov. 2020.

G1. Brasil dobra número de países em monitoramento de casos suspeitos de novo coronavírus; Itália, França e Alemanha entram na lista. Disponivel em: https://g1.globo.com/ciencia-e- 
saude/noticia/2020/02/24/brasil-dobra-numero-de-paises-em-monitoramento-de-casos-suspeitos-denovo-coronavirus-italia-franca-e-alemanha-entram-na-lista.ghtml. Acesso em: 19 nov. 2020.

GAZETA DO POVO. Senegal registra primeiro caso de coronavírus Coronavírus chega ao Senegal. Disponível em: https://www.gazetadopovo.com.br/mundo/breves/senegal-registra-casocoronavirus/. Acesso em: 18 nov. 2020.

GLOBAL, I. Iris Global | Missionary NGO to Mozambique, Africa \& the World, Sponsor a Child, School for Ministry. Disponível em: https://www.irisglobal.org. Acesso em: 18 nov. 2020.

GONÇALVES, R. S.; BAUTĖS, N.; MANEIRO, M. A Informalidade Urbana em Questão. 0 social em questão, v. 42, p. 9-26, dez. 2018.

IBGE. Duque de Caxias (RJ) | Cidades e Estados | IBGE. Disponível em: https://www.ibge.gov.br/cidades-e-estados/rj/duque-de-caxias.html. Acesso em: 19 nov. 2020a.

IBGE. Rio de Janeiro. Disponível em: https://cidades.ibge.gov.br/brasil/rj/panorama. Acesso em: 19 nov. 2020b.

IBGE NOTÍCIAS. Desocupação cai para 12,3\% no ano com recorde de pessoas na informalidade. Disponível em: https://agenciadenoticias.ibge.gov.br/agencia-noticias/2012-agencia-denoticias/noticias/23652-desocupacao-cai-para-12-3-no-ano-com-recorde-de-pessoas-na-informalidade. Acesso em: 19 nov. 2020.

ILO. The Summary Report on Enabling Environment for Sustainable Enterprises in Mozambique 2019. [s.l: s.n.]. Disponível em: http://www.ilo.org/empent/Publications/WCMS_731284/lang-en/index.htm. Acesso em: 18 nov. 2020.

INE. Cabo Delgado - Instituto Nacional de Estatistica. Disponível em:

http://www.ine.gov.mz/estatisticas/estatisticas-territorias-distritais/cabo-delgado. Acesso em: 18 nov. 2020.

INE. IV Censo 2017 - Instituto Nacional de Estatistica. Disponível em: http://www.ine.gov.mz/ivcenso-2017. Acesso em: 18 nov. 2020.

INS. Início. Disponível em: https://covid19.ins.gov.mz/. Acesso em: 19 nov. 2020.

JORNAL TXOPELA. Covid-19: Pandemia está a expor desigualdades sociais em Moçambique filósofo. Disponível em: https://www.jornaltxopela.com/2020/04/covid-19-pandemia-esta-a-expordesigualdades-sociais-em-mocambique-filosofo/. Acesso em: 18 nov. 2020a.

JORNAL TXOPELA. Covid-19: "Líderes juvenis devem ser mais proactivos" - Oswaldo Peterburgo. Disponível em: https://www.jornaltxopela.com/2020/05/covid-19-lideres-juvenis-devemser-mais-proactivos-oswaldo-peterburgo/. Acesso em: 18 nov. $2020 \mathrm{~b}$.

KRIPPAHL, C. Coronavírus em África: Medidas a mais ou a menos? | DW | 24.03.2020. Disponível em: https://www.dw.com/pt-002/coronav\%C3\%ADrus-em-\%C3\%A1frica-medidas-a-mais-ou-amenos/a-52899109. Acesso em: 18 nov. 2020. 
LEMOS, V. O que a ciência diz sobre a eficácia de tratamentos citados por Bolsonaro ao revelar que está com covid-19. BBC News Brasil, 2020.

LUPION, B. Como o novo coronavírus acentua as desigualdades no Brasil | DW | 27.04.2020.

Disponível em: https://www.dw.com/pt-br/como-o-novo-coronav\%C3\%ADrus-acentua-asdesigualdades-no-brasil/a-53256164. Acesso em: 19 nov. 2020.

LUTXEQUE, S. Covid-19: Menores de Nampula relatam episódios de abusos da polícia | DW | 16.06.2020. Disponível em: https://www.dw.com/pt-002/covid-19-menores-de-nampula-relatamepis\%C3\%B3dios-de-abusos-da-pol\%C3\%ADcia/a-53825588. Acesso em: 18 nov. 2020.

MATIAS, L. Cabo Delgado: Estudo aponta pobreza como causa de ataques armados | DW | 19.07.2019. Disponível em: https://www.dw.com/pt-002/cabo-delgado-estudo-aponta-pobreza-comocausa-de-ataques-armados/a-49658029. Acesso em: 18 nov. 2020.

MATIAS, L. Moçambique: Comerciantes são os mais vulneráveis à Covid-19 em Maputo | DW | 31.08.2020. Disponível em: https://www.dw.com/pt-002/mo\%C3\%A7ambique-comerciantess\%C3\%A3o-os-mais-vulner\%C3\%A1veis-\%C3\%A0-covid-19-em-maputo/a-54774765. Acesso em: 18 nov. 2020.

MGCAS; INAS. PLANO DE RESPOSTA À COVID-19 EM MOÇAMBIQUE - PROTECÇÃO SOCIAL. Disponível em:

https://www.unicef.org/mozambique/media/2886/file/PLANO $\% 20 D E \% 20 R E S P O S T A \% 20 \% C 3 \% 80 \% 20$ COVID-19\%20EM\%20MO\%C3\%87AMBIQUE\%20-

\%20PROTEC\%C3\%87\%C3\%830\%20SOCIAL.pdf>. Acesso em: 18 nov. 2020.

MONIÉ, F. A África subsaariana diante da pandemia de Coronavírus/COVID-19: difusão espacial, impactos e desafios. Espaço e Economia. Revista brasileira de geografia econômica, n. 18, 21 abr. 2020.

MSF. MSF reage à catástrofe em Moçambique com operação de grandes proporções. Disponível em: https://www.msf.org.br/noticias/msf-reage-catastrofe-em-mocambique-com-operacao-de-grandesproporcoes. Acesso em: 18 nov. 2020.

MUNDO AO MINUTO. Covid-19. Pemba passa a ter maior centro de tratamento de Moçambique. Disponível em: https://www.noticiasaominuto.com/mundo/1575759/covid-19-pemba-passa-a-ter-maiorcentro-de-tratamento-de-mocambique. Acesso em: 18 nov. 2020.

NORONHA, P. H. Letalidade por Covid-19 no Rio está acima da média mundial. Disponível em: https://portal.fiocruz.br/noticia/letalidade-por-covid-19-no-rio-esta-acima-da-media-mundial. Acesso em: 19 nov. 2020.

O FLUMINENSE. Hospital Municipal para tratamento da Covid-19 é inaugurado em Duque de Caxias. Disponível em: https://www.ofluminense.com.br/editorias/cidades/2020/05/1139896-hospitalmunicipal-para-tratamento-da-covid-19-e-inaugurado-em-duque-de-caxias.html. Acesso em: 19 nov. 2020.

O GLOBO. Necrotério do Hospital Moacyr do Carmo, em Caxias, está lotado e cadáveres estão até nos corredores. Disponível em: https://oglobo.globo.com/rio/necroterio-do-hospital-moacyr-do- 
carmo-em-caxias-esta-lotado-cadaveres-estao-ate-nos-corredores-24393841. Acesso em: 19 nov. 2020.

OLINTO, R. Economia informal: setor informal, emprego informal, afinal do que estamos verdadeiramente falando - Parte I| Blog do IBRE. Disponível em:

https://blogdoibre.fgv.br/posts/economia-informal-setor-informal-emprego-informal-afinal-do-queestamos-verdadeiramente. Acesso em: 19 dez. 2020.

OLIVEIRA, A. S.; RIBEIRO, V. DE O. Análise geral da evolução do emprego celetista em Uberlândia: 0 primeiro quadrimestre de 2020 no contexto da crise da Covid-19. p. 8, 2020.

OLIVEIRA, R.; BORGES, R.; BEDINELLI, T. Mapa da covid-19 no Brasil: Evolução dos casos de coronavírus no Brasil | Atualidade | EL PAíS Brasil. Disponível em:

https://brasil.elpais.com/ciencia/2020-07-23/evolucao-dos-casos-de-coronavirus-no-brasil.html. Acesso em: 18 nov. 2020.

ONU. PMA atua em parceria para melhorar alerta de secas em Moçambique. Disponível em: https://news.un.org/pt/story/2020/11/1732922. Acesso em: 18 nov. 2020.

OPAS; OMS. Folha informativa COVID-19 - Escritório da OPAS e da OMS no Brasil - OPAS/OMS | Organização Pan-Americana da Saúde. Disponível em: http://www.paho.org/pt/covid19. Acesso em: 18 nov. 2020a.

OPAS; OMS. OPAS/OMS Brasil - OMS afirma que COVID-19 é agora caracterizada como pandemia | OPAS/OMS. Disponível em:

https://www.paho.org/bra/index.php?option=com_content\&view=article\&id=6120:oms-afirma-que-covid19-e-agora-caracterizada-como-pandemia\&ltemid=812. Acesso em: 18 nov. $2020 \mathrm{~b}$.

PINHEIRO, L. Brasil reduz testes de Covid em setembro, e especialistas alertam: taxa de positivos segue alta. Disponível em:

https://g1.globo.com/bemestar/coronavirus/noticia/2020/10/21/brasil-reduz-testes-de-covid-emsetembro-e-especialistas-alertam-taxa-de-positivos-segue-alta.ghtml. Acesso em: 19 nov. 2020.

PINTO, A. E. DE S. Brasil entra em rede global de produção de vacinas contra Covid-19. Disponível em: https://www1.folha.uol.com.br/equilibrioesaude/2020/06/brasil-entra-em-rede-global-deproducao-de-vacinas-contra-covid-19.shtml. Acesso em: 19 nov. 2020.

PNADC. Características gerais dos domicílios e dos moradores : 2019. Disponível em: https://biblioteca.ibge.gov.br/index.php/biblioteca-catalogo?view=detalhes\&id=2101707. Acesso em: 19 nov. 2020.

PNADC. Pesquisa Nacional por Amostra de Domicílios Contínua - PNAD Contínua | IBGE. Disponivel em: https://www.ibge.gov.br/estatisticas/multidominio/condicoes-de-vida-desigualdade-epobreza/17270-pnad-continua.html?edicao=27258\&t=resultados. Acesso em: 5 nov. 2020.

REGUEIRA, C. Alunos de Duque de Caxias, RJ, aguardam auxílio prometido pela prefeitura há dois meses. Disponível em: https://g1.globo.com/rj/rio-de-janeiro/noticia/2020/05/06/alunos-de-duquede-caxias-rj-aguardam-auxilio-prometido-pela-prefeitura-ha-dois-meses.ghtml. Acesso em: 19 nov. 2020. 
RIO DE JANEIRO. Boletim Coronavírus (05/11): 20.849 óbitos e 313.843 casos confirmados no RJCoronaVírus RJ, 2020. Disponível em: https://coronavirus.rj.gov.br/boletim/boletim-coronavirus-0511-20-849-obitos-e-313-843-casos-confirmados-no-rj/. Acesso em: 19 nov. 2020.

RIOS, B.; LIMA, R. Baixo número de testes deixa Brasil mais vulnerável à segunda onda da covid-19. Disponível em: https://www.correiobraziliense.com.br/brasil/2020/11/4886274-baixo-numerode-testes-deixa-brasil-mais-vulneravel-a-segunda-onda-da-covid-19.html. Acesso em: 19 nov. 2020.

ROUBICEK, M. Os dados do desemprego e a fragilidade do trabalho informal. Disponível em: https://www.nexojornal.com.br/expresso/2020/08/06/Os-dados-do-desemprego-e-a-fragilidade-dotrabalho-informal. Acesso em: 19 nov. 2020a.

ROUBICEK, M. Os primeiros efeitos da redução do auxílio emergencial na economia. Disponível em: https://www.nexojornal.com.br/expresso/2020/11/13/Os-primeiros-efeitos-daredu\%C3\%A7\%C3\%A3o-do-aux\%C3\%ADlio-emergencial-na-economia. Acesso em: 19 nov. 2020b.

SANTIRSO, J. Vírus letal da China se espalha e alcança Coreia do Sul. Disponível em: https://brasil.elpais.com/internacional/2020-01-20/virus-letal-de-wuhan-se-espalha-pela-china.html. Acesso em: 18 nov. 2020.

SIC NOTÍCIAS. SIC Notícias | Vendedores de rua desafiam a Covid-19 para fugir à fome em Maputo. Disponível em: //sicnoticias.pt/mundo/2020-08-22-Vendedores-de-rua-desafiam-a-Covid-19para-fugir-a-fome-em-Maputo. Acesso em: 18 nov. 2020.

SILVA, K. N. D. EXPANSÃO URBANA DO SETOR SUL DA CIDADE DE UBERLÂNDIA-MG: um estudo dos processos de exclusão. p. 150, 2012.

SILVA, V. H. Justiça suspende ordem para iFood pagar entregadores afastados | Legislação. Disponível em: https://tecnoblog.net/333344/justica-suspende-ordem-ifood-pagar-entregadoresafastados/. Acesso em: 19 nov. 2020.

SIMONI, C. 0 coronavírus e o direito à cidade dos pobresCartaCapital, 17 abr. 2020. Disponível em: https://www.cartacapital.com.br/opiniao/o-coronavirus-e-o-direito-a-cidade-dos-pobres/. Acesso em: 19 nov. 2020.

TORRES. Duque de Caxias, no RJ, segue decreto de Witzel e reabre comércio e bares; cidades têm autonomia para decidir. Disponivel em: https://g1.globo.com/rj/rio-dejaneiro/noticia/2020/06/08/duque-de-caxias-no-rj-segue-decreto-de-witzel-e-reabre-comercio-e-barescidades-tem-autonomia-para-decidir.ghtml. Acesso em: 19 nov. 2020a.

TORRES, L. Após confirmar primeiro óbito, Duque de Caxias, RJ, adota medidas restritivas contra o novo coronavírus. Disponível em: https://g1.globo.com/rj/rio-de-

janeiro/noticia/2020/04/03/apos-confirmar-primeiro-obito-duque-de-caxias-rj-adota-medidas-restritivascontra-o-novo-coronavirus.ghtml. Acesso em: 19 nov. $2020 \mathrm{~b}$.

TV DE MOÇAMBIQUE. Álcool gel 70 por cento: Universidade Pedagógica de Maputo já dispõe do produto, com base em material local. Disponível em:

https://www.tvm.co.mz/index.php?option=com_k2\&view=item\&id=7067:alcool-gel-70-por-centouniversidade-pedagogica-de-maputo-ja-dispoe-do-produto-com-base-em-material-local\&ltemid=277. Acesso em: 18 nov. 2020. 
VANNUCHI, C. A pandemia de Covid-19 segundo Bolsonaro: da "gripezinha" ao "e daí?" Disponível em: https://noticias.uol.com.br/colunas/camilo-vannuchi/2020/04/30/a-pandemia-de-covid19-segundo-bolsonaro-da-gripezinha-ao-e-dai.htm. Acesso em: 19 nov. 2020. 